\title{
INHIBITION OF FERTILIZATION IN VIVO BY PANCREATIC AND SEMINAL PLASMA TRYPSIN INHIBITORS
}

\author{
L. J. D. ZANEVELD, R. T. ROBERTSON, M. KESSLER* \\ AND W. L. WILLIAMS \\ Department of Biochemistry, University of Georgia, \\ Athens, Georgia 30601, U.S.A. \\ (Received 16th Fuly 1970)
}

\begin{abstract}
Summary. Treatment of capacitated rabbit spermatozoa with pancreatic trypsin inhibitor or partially purified seminal plasma trypsin inhibitor and subsequent insemination of such spermatozoa into the oviducts of ovulated rabbits markedly inhibited fertilization. Washing the spermatozoa to remove excess inhibitor did not affect the antifertility action of pancreatic trypsin inhibitor. Seminal plasma trypsin inhibitor was purified by specific binding to a trypsin-maleic anhydride-ethylene copolymer and Sephadex G-25 and G-50 column chromatography. A 500 -fold purification was obtained.
\end{abstract}

\section{INTRODUCTION}

A trypsin-like enzyme has been known to exist in mammalian spermatozoa for many years (Yamane, 1935a, b; Buruiana, 1956) and has recently been shown to be localized in the sperm acrosome (Stambaugh \& Buckley, 1969; Zaneveld, Srivastava \& Williams, 1969; Zaneveld \& Williams, 1970). Although the enzyme is similar to trypsin and plasmin and is inhibited by trypsin inhibitors, it has some unique properties (Zaneveld, Polakoski \& Williams in preparation) and we therefore propose the name 'acrosin' based on the nomenclature for proteolytic enzymes where the prefix refers to the source of the enzyme. Unfortunately the name 'acrosomin' has already been used to indicate a mucopolysaccharide in the acrosome (Clermont \& Leblond, 1955). Acrosin appears to be used by spermatozoa to penetrate the zona pellucida of the ovum. Acrosomal extracts of epididymal and capacitated spermatozoa have high acrosin activity whereas activity cannot be detected in acrosomal extracts of ejaculated spermatozoa until after chromatography of the extracts (Zaneveld et al., 1969). Treatment of epididymal spermatozoa with seminal plasma decreases acrosin activity and epididymal spermatozoa appear to acquire a trypsin inhibitor by contact with seminal plasma, the inhibitor being removed during capacitation or in acrosomal extracts by purification of acrosin (Zaneveld, Srivastava \& Williams, 1970).

* Present address: University of Augusta Medical School, Augusta, Ga. 30902, U.S.A. 
Haendle, Fritz, Trautschold \& Werle (1965) and Fritz, Schult, Hutzel, Wiedemann \& Werle (1967) isolated a trypsin inhibitor from the seminal vesicles of mice using a resin to which trypsin was attached that specifically bound the inhibitor. This seminal vesicle trypsin inhibitor possessed many similarities to bovine pancreatic trypsin inhibitor, both having a molecular weight of approximately 6000 and a similar amino acid composition. Stambaugh, Brackett \& Mastroianni (1969) showed that fertilization in vitro was inhibited by soybean trypsin inhibitor.

This report concerns the partial purification of rabbit seminal plasma trypsin inhibitor (SPTI) and the inhibition of fertilization in vivo by SPTI and pancreatic trypsin inhibitor.

\section{MATERIALS AND METHODS}

\section{Isolation of seminal plasma trypsin inhibitor}

Trypsin-maleic anhydride-ethylene copolymer was prepared according to the method of Levin, Pecht, Goldstein \& Katchalski (1964). Four hundred mg of pure bovine pancreatic trypsin (Worthington Biochemical Company) combined with $1 \mathrm{~g}$ of maleic anhydride-ethylene copolymer (EMA31, Monsanto Company) to form the trypsin resin.

Semen was collected three times a week from forty New Zealand White rabbits. The spermatozoa were removed by centrifugation and the seminal plasma pooled and stored at $-20^{\circ} \mathrm{C}$. High molecular weight material, including decapacitation factor $(\mathrm{DF})$, was removed from the seminal plasma by centrifuging at 105,000 $\mathrm{g}$ for $4 \mathrm{hr}$ (Bedford \& Chang, 1962). The supernatant solution was incubated at $37^{\circ} \mathrm{C}$ for 20 min with $1.4 \mathrm{~g}$ of lyophilized trypsin resin while shaking. The mixture was centrifuged at $6000 \mathrm{~g}$ for $15 \mathrm{~min}$ at $0^{\circ} \mathrm{C}$ and the supernatant solution removed. The precipitate was washed by centrifugation with $0.1 \mathrm{~m}$-triethanolamine buffer, $\mathrm{pH} 8$, containing $0.1 \mathrm{~m}-\mathrm{NaCl}$, until no protein could be detected in the supernate. The bound SPTI was removed from the trypsin-resin by suspension of the precipitate in $0 \cdot 1 \mathrm{M}-\mathrm{KCl}-\mathrm{HCl}$ buffer at $\mathrm{pH} 2$ and incubated for $15 \mathrm{~min}$ at $37^{\circ} \mathrm{C}$. The suspension was again centrifuged at $6000 \mathrm{~g}$ for $15 \mathrm{~min}$ at $0^{\circ} \mathrm{C}$ and the supernatant solution collected. This was repeated three times to release all the bound inhibitor. The trypsin resin was washed twice with glass-distilled water and lyophilized. The lyophilized copolymer is stable and can be used repeatedly.

The supernatant solutions were concentrated by flash-evaporation to $5 \mathrm{ml}$ and desalted using a Sephadex G-25 column and elution with water at room temperature. The excluded fraction containing SPTI was lyophilized and used in the fertilization assays.

Seminal plasma trypsin inhibitor was further purified by addition of $20 \mathrm{mg}$ lyophilized material to a Sephadex G-50 column and elution with $0.01 \mathrm{M}$ phosphate buffer, $\mathrm{pH} 7 \cdot 0$, at a rate of $10 \mathrm{drops} / \mathrm{min}$.

Trypsin inhibitor assays were performed by incubating $0.1 \mathrm{ml}$ of the inhibitor solution with $0.1 \mathrm{ml}$ pancreatic trypsin (Worthington, twice crystallized), for $15 \mathrm{~min}$ at $25^{\circ} \mathrm{C}$ and assaying $0.1 \mathrm{ml}$ of the mixture for trypsin activity by the method of Schwert \& Takenake (1955) using benzoyl-arginine ethylester 
(BAEE, Mann Res. Lab.) as substrate. Controls were similarly treated except that no trypsin inhibitor was present. Trypsin activity $(1 \mathrm{mU})$ was defined as that amount of trypsin causing a rate of change of 0.001 optical density units/ min. The purity of the SPTI-containing peaks was estimated by disc electrophoresis on polyacrylamide gel (Brewer \& Ashworth, 1969).

\section{Fertilization procedure in-vivo}

Capacitated spermatozoa were obtained from mature New Zealand White rabbits by the method of Williams, Hamner, Weinman \& Brackett (1964). Two hundred $\mu \mathrm{g}$ of pancreatic trypsin inhibitor (Worthington, crystallized) or $250 \mu \mathrm{g}$ of SPTI were added to $10^{5}$ spermatozoa and the suspension incubated for 15 $\min$ at $37^{\circ} \mathrm{C}$. This amount of inhibitor is similar to that of low molecular weight DF (Williams, Robertson \& Dukelow, 1969) usually employed in these
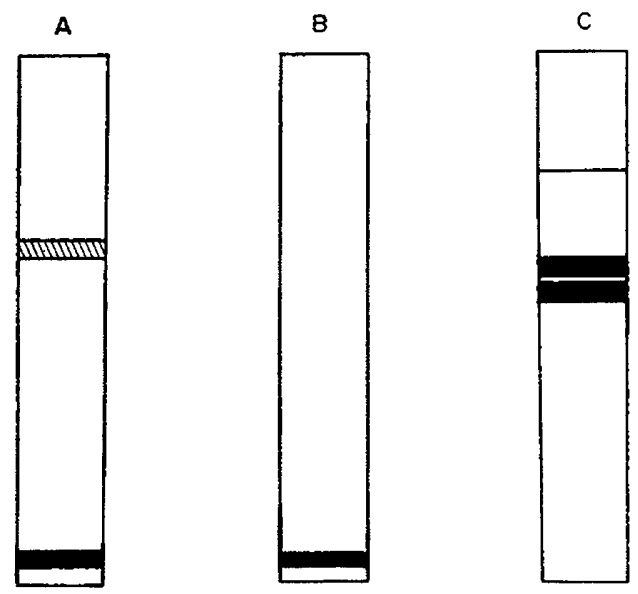

TEXT-FIG. 1. Disc electrophoresis of partially purified fractions containing seminal plasma trypsin inhibitor. Disc electrophoresis was performed at $\mathrm{pH} \mathrm{8.3} \mathrm{(A} \mathrm{and} \mathrm{B}$ ) and 4.3 (C). (A) After desalting by Sephadex G-25; (B and C) After Sephadex G-50 chromatography.

assays. A larger amount of SPTI than pancreatic trypsin inhibitor (PTI) was used since the SPTI was less pure.

Human chorionic gonadotrophin (75 units, Spencer Mead, Inc.) was injected (i.v.) $12 \frac{1}{2} \mathrm{hr}$ before surgical insemination into mature, New Zealand White rabbits that had been kept in isolation for at least 18 days. One oviduct was used for the treated spermatozoa and the other for the control spermatozoa. A $0.25-\mathrm{ml}$ syringe with a small Teflon needle was used to inseminate $0.05 \mathrm{ml}$ $\left(5 \times 10^{4}\right.$ spermatozoa $)$ of the sperm solution. The rabbits were killed $24 \mathrm{hr}$ later, the ova flushed from the oviducts with Krebs-Ringer-phosphate and observed for cleavage. Overall egg recovery averages $85 \%$ in our laboratories.

\section{RESULTS}

Disc electrophoresis at $\mathrm{pH} 8.3$ revealed the presence of one major and one minor component in the peak containing SPTI after Sephadex G-25 chromatography 
(Text-fig. 1). The minor component was removed by further purification. Three components were obtained after Sephadex G-50 chromatography (Text-fig. 2). The major retarded component contained all the SPTI activity. This compo-

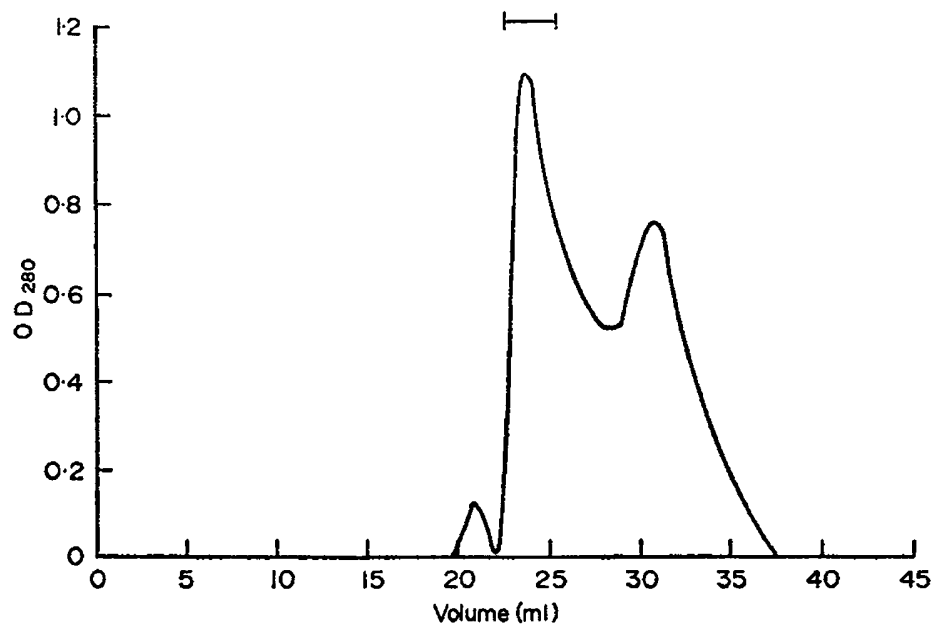

TexT-FIg. 2. Elution profile of seminal plasma trypsin inhibitor (SPTI) subjected to Sephadex G-50 chromatography. Protein was eluted with $0.01 \mathrm{M}$-phosphate buffer, $\mathrm{pH}$ 7.0. Horizontal bar indicates pooled fractions containing SPTI.

TABLE 1

EFFECT OF MAMMALIAN TRYPSIN INHIBITORS ON FERTILIZATION IN VIVO

\begin{tabular}{l|c|c|c}
\hline \multicolumn{1}{c|}{$\begin{array}{c}\text { Treatment of } \\
\text { spermatozoa }\end{array}$} & $\begin{array}{c}\text { No. of } \\
\text { rabbits }\end{array}$ & $\begin{array}{c}\text { Cleaved ova/ } \\
\text { total no. of ova }\end{array}$ & \% fertilization \\
\hline $\begin{array}{l}\text { Pancreatic trypsin inhibitor } \\
\left(200 \mu \mathrm{g} / 10^{5} \text { spermatozoa) }\right.\end{array}$ & 10 & $8 / 49$ & $16 \cdot 3$ \\
Control & 10 & $28 / 37$ & $75 \cdot 7$ \\
\hline $\begin{array}{l}\text { Pancreatic trypsin inhibitor } \\
\left(200 \mu \mathrm{g} / 10^{5} \text { spermatozoa) }\right.\end{array}$ & 7 & $2 / 22$ & $9 \cdot 1$ \\
\begin{tabular}{l} 
Control \\
\hline Seminal plasma trypsin inhibitor \\
$\left(250 \mu \mathrm{g} / 10^{5}\right.$ spermatozoa)
\end{tabular} & 5 & $15 / 22$ & $68 \cdot 2$ \\
Control & 5 & $1 / 14$ & $7 \cdot 1$ \\
\hline
\end{tabular}

The mixture of trypsin and spermatozoa $\left(0.05 \mathrm{ml}, 5 \times 10^{5}\right.$ spermatozoa) was inseminated into the oviducts of rabbits $12 \frac{1}{2} \mathrm{hr}$ after administration of HCG, except in the second group of experiments in which the trypsin inhibitor was removed from the spermatozoa by centrifugation at $300 \mathrm{~g}$ for $5 \mathrm{~min}$, discarding the supernatant solution and resuspending the spermatozoa in Krebs-Ringer-phosphate.

Controls were treated in the same way as the test samples, except that no trypsin inhibitor was added.

One $\mu \mathrm{g}$ pancreatic trypsin inhibitor inhibits $3.6 \mathrm{mU}$ pancreatic trypsin. One $\mu \mathrm{g}$ seminal plasma trypsin inhibitor inhibits $2.4 \mathrm{mU}$ pancreatic trypsin.

nent showed one band by disc electrophoresis at $\mathrm{pH} 8 \cdot 3$. At $\mathrm{pH} 4 \cdot 3$, two major adjacent bands and one faint band were obtained (Text-fig. 1). After Sephadex G-50 chromatography, SPTI had on a weight basis approximately a 500-fold 
greater inhibitory effect on pancreatic trypsin than seminal plasma. One microgram of SPTI caused the inhibition of $10 \mathrm{mU}$ pancreatic trypsin.

The motility of the capacitated spermatozoa was not affected by incubation with either PTI or SPTI if the preparations were salt-free. Both SPTI and PTI depressed fertilization (Table 1). SPTI caused $87.4 \%$ inhibition of fertility compared with the controls. The presence of trypsin inhibitor in the oviduct did not affect the fertility since approximately the same percentage inhibition of fertilization was obtained $(59.4 \%$ versus $59.1 \%)$ if spermatozoa were inseminated with PTI or if the excess PTI was first removed by centrifugation and the spermatozoa resuspended in Krebs-Ringer-phosphate.

\section{DISCUSSION}

The results indicate that, besides DF, another enzyme inhibitor, SPTI, is present in the seminal plasma that can prevent fertilization. It is unlikely that the inhibition of fertilization by SPTI is caused by residual DF since all DF is removed from the seminal plasma by centrifugation at $105,000 \mathrm{~g}$ for $4 \mathrm{hr}$. Further, DF is not a trypsin inhibitor (Zaneveld \& Williams, 1970) and will not bind to the trypsin-resin.

Fertilization can also be inhibited using PTI. Most likely SPTI and PTI act by inhibiting acrosin, a proteolytic enzyme present in the sperm acrosome so that penetration of the spermatozoa through the zona pellucida is no longer possible.

The trypsin inhibitor must pass through the outer acrosomal membrane to contact acrosin. It is therefore not surprising that high levels of soybean trypsin inhibitor were necessary to prevent fertilization in vitro (Stambaugh et al., 1969). The molecular weight of soybean trypsin inhibitor is three to four times higher than most mammalian trypsin inhibitors and may penetrate the outer acrosomal membrane with difficulty.

Bedford \& Chang (1962) found that the supernatant solution after centrifugation of rabbit seminal plasma at $105,000 \mathrm{~g}$ has little DF activity. Although SPTI is present in this supernatant solution, the amount of SPTI is probably too small to prevent fertilization. It is possible, however, that the small decreases in fertility $(0$ to $35 \%$ ) caused by the supernatant solutions were due to the SPTI.

A high degree of purity of the seminal plasma trypsin inhibitor has been obtained. The faint band after electrophoresis at $\mathrm{pH} 4 \cdot 3$ is probably a contaminant but the heavy bands may both be caused by trypsin inhibitors of similar molecular weight since Fritz et al. (1967) obtained the same results when purifying a trypsin inhibitor from the seminal vesicles of mice. They showed the presence of two almost identical inhibitors possessing a molecular weight of approximately 6000 . Since the SPTI is retarded by Sephadex G-50, its molecular weight might be in the same range. It appears quite likely that SPTI and the seminal vesicle trypsin inhibitor are the same or similar inhibitors.

\section{ACKNOWLEDGMENTS}

This research was supported by Training Grant No. 5-T01-HD00140-04 from 
the National Institute of Child Health and Human Development; Career Development Award No. 2-K3-GM4831 from the National Institute of Medical Sciences; Contracts NIH-70-2147 and NIH-69-2103 with the National Institutes of Health, Department of Health, Education and Welfare; and a Ford Foundation Grant. We thank L. Patrick and L. Chaffin for their assistance in animal care and surgery.

\section{REFERENCES}

Bedford, J. M. \& Chang, M. G. (1962) Removal of decapacitation factor from seminal plasma by high-speed centrifugation. Am. F. Physiol. 202, 179.

Brewer, J. M. \& Ashworth, R. B. (1969) Disc electrophoresis. 7. chem. Educ. 46, 41.

BuRUiana, L. M. (1956) Sur l'activité-hyaluronidasique et trypsinique du sperme. Naturwissenschaften, $43,523$.

Clermont, Y. \& Leblond, C. P. (1955) Spermiogenesis of man, monkey, ram and other mammals as shown by the "periodic acid-Schiff" technique. Am. F. Anat. 96, 229.

Fritz, H., Schult, H., Hutzel, M., Wiedemann, M. \& Werle, E. (1967)Isolierung von ProteaseInhibitoren mit Hilfe Wasserunlöslicher Enzyme-Harze. Hoppe-Seyler's Z. physiol. Chem. 348, 308.

Haendle, H., Fritz, H., Trautschold, I. \& Werle, E. (1965) Über einen hormonabhängigen Inhibitor fur proteolytische Enzyme in männlichen accessorischen Geschlechtsdrüsen und im Sperma. Hoppe-Seyler's Z. physiol. Chem. 343, 185.

Levin, Y., PECht, M. Goldstein, L. \& KATGhalski, E. (1964) A water insoluble polyanionic derivative of trypsin. I. Preparation and properties. Biochemistry, 3, 1905.

Schwert, G. W. \& TAKenake, Y. (1955) A spectrophotometric determination of trypsin and chymotrypsin. Biochim. biophys. Acta, 16, 570 .

Stambaugh, R., Brackett, B. G. \& MAStroiann, L. (1969) Inhibition of in vitro fertilization of rabbit ova by trypsin inhibitors. Biol. Reprod. 1, 223.

Stambaugh, R. \& Buckley, J. (1969) Identification and subcellular localization of the enzymes effecting penetration of the zona pellucida by rabbit spermatozoa. F. Reprod. Fert. 19, 423.

Williams, W. L., Hamner, C. E., Weinman, D. E. \& Brackett, B. G. (1964) Capacitation of rabbit spermatozoa and initial experiments on in vitro fertilization. $V^{\circ}$ Congresso Intern. Riprod. Animale Fecond. Artif., Trento, 7, 288.

Williams, W. L., Robertson, R. T. \& Dukelow, R. W. (1969) Decapacitation factor and capacitation. Symp. on Mechanisms Involved in Conception, Adv. in Biosciences, 4, 61.

Yamane, J. (1935a) Kausel-analytischen Studien über die Befruchtung des Kanincheneies. I. Die Dispersion der Follikelzellen und die Ablösung der Zellen der Corona Radiata des Eies durch spermatozoen. Cytologia, 6, 233.

Yamane, J. (1935b) Kausel-analytische Studien über die Befruchtung des Kanincheneies. II. Die Isolierung der auf das Eizytplasma auflösund wirkenden Substanzen aus den Spermatozoen. Cytologia, 6, 475.

Zaneveld, L.J. D., Srivastava, P. N. \& Williams, W. L. (1969) Relationship of a trypsin-like enzyme in rabbit spermatozoa to capacitation. F. Reprod. Fert. 20, 337.

Zaneveld, L. J. D., Srivastava, P. N. \& Williams, W. L. (1970) Inhibition by seminal plasma of acrosomal enzymes in intact sperm. Proc. Soc. exp. Biol. Med. 133, 1172.

ZANEVELD, L. J. D. \& Williams, W. L. (1970) A sperm enzyme that disperses the corona radiata and its inhibition by decapacitation factor. Biol. Reprod. 2, 363 . 